\begin{abstract}
OU Negeo
International Journal of Environment and Geoinformatics (IJEGEO) is an international, multidisciplinary, peer reviewed, open access journal.
\end{abstract}

\title{
Geomorphological features of Marmara Sea Islands
}

\section{Hakan KAYA}

\section{Chief in Editor}

Prof. Dr. Cem Gazioğlu

\section{Co-Editor}

Prof. Dr. Dursun Zafer Şeker, Prof. Dr. Şinasi Kaya, Prof. Dr. Ayşegül Tanık and Assist. Prof. Dr. Volkan Demir

\section{Editorial Committee (2019)}

Assos. Prof. Dr. Abdullah Aksu (TR), Prof. Dr. Bedri Alpar (TR), Prof. Dr. Lale Balas (TR), Prof. Dr. Levent Bat (TR), Prof. Dr. Paul Bates (UK), Prof. Dr. Bülent Bayram (TR), Prof. Dr. Luis M. Botana (ES), Prof. Dr. Nuray Çağlar (TR), Prof. Dr. Sukanta Dash (IN), Dr. Soofia T. Elias (UK), Prof. Dr. A. Evren Erginal (TR), Assoc. Prof. Dr. Cüneyt Erenoğlu (TR), Dr. Dieter Fritsch (DE), Assos. Prof. Dr. Çiğdem Göksel (TR), Prof.Dr. Lena Halounova (CZ), Dr. Hakan Kaya (TR), Assoc. Prof. Dr. Maged Marghany (MY), Prof. Dr. Michael Meadows (ZA), Prof. Dr. Nebiye Musaoğlu (TR), Prof. Dr. Erhan Mutlu (TR), Prof. Dr. Masafumi Nakagawa (JP), Prof. Dr. Hasan Özdemir (TR), Prof.Dr. Chryssy Potsiou (GR), Prof. Dr. Erol Sarı (TR), Prof. Dr. Maria Paradiso (IT), Prof. Dr. Petros Patias (GR), Prof. Dr. Elif Sertel (TR), Prof. Dr. Nüket Sivri (TR), Assoc. Prof. Dr. Füsun Balık Şanlı (TR), Prof. Dr. Uğur Şanlı (TR), Assoc. Prof. Dr. Oral Yağcı (US), Prof. Dr. Seyfettin Taş (TR), Assoc. Prof. Dr. Ömer Suat Taşkın (TR), Dr. İnese Varna (LV), Dr. Petra Visser (NL), Prof. Dr. Selma Ünlü (TR), Assoc. Prof. Dr. İ. Noyan Yılmaz (AU), Prof. Dr. Murat Yakar (TR), Assit. Prof. Dr. Sibel Zeki (TR) 
Reaserch Article

\title{
Geomorphological features of Marmara Sea Islands
}

\author{
Hakan Kaya ID \\ Istanbul University, Institute of Marine Sciences and Management, 34134 VEFA Fatih Istanbul TR
}

E-mail:dr.hakankaya@hotmail.com

Received 28 Feb 2019

Accepted 26 March 2019

How to cite: Kaya, H.(2019). Geomorphological features of Sea of Marmara Islands, International Journal of Environment and

Geoinformatics (IJEGEO), 6(1): 57-66. DOI: 10.30897/ijegeo.533694

\begin{abstract}
The Sea of Marmara is located on a continental crust. The Sea of Marmara, which is a remnant of the Sarmasien period of the Miocene Sea, is an inland sea (Okay, 2007). It opens to the Black Sea with the Bosphorus and the Aegean Sea with the Dardanelles. Its surface area is 11111 km2 (Gazioğlu, et al., 2002) and its average depth ranges from -200 to -500 m (Doganay, 1997). At the end of the third time, and at the beginning of the fourth time, there were crumbs and crashes arising from the earth crust movements in and around, where this sea lies today (İzbirak, 1996). In the Marmara Sea, the oldest sediments were deposited as a result of the transformation of the Marmara Sea from a lacustrine environment to a marine environment with the Mediterranean Tyrenian transgression at the end of Middle Pleistocene. When the sea level in the Sea of Marmara is at the same or higher than the present day, water passage from the Black Sea has occurred. At the beginning of Late Pleistocene, as a result of a sudden drop in world sea level, the water passage from the Marmara Sea to the Mediterranean was cut and the marine sedimentation environment was replaced by lacustrine sedimentation. At the beginning of Late Pleistocene (between 64.000-59.000 BC), Mediterranean waters entered the Sea of Marmara and the Black Sea with the sudden rise of sea level (Algan, et al., 2011 ). After the transgression, the gulfs and islands in the Sea of Marmara were formed.
\end{abstract}

Keywords: Sea of Marmara Islands, Marmara, Avşa, Paşalimanı, Büyükada, Heybeliada

\section{Introduction}

The Sea of Marmara is an inland sea in NW Anatolia, which is located between the Aegean Sea in the south and the Black Sea in the north. It has a surface area of 11 $110 \mathrm{~km} 2$ (max. $280 \mathrm{~km}$. long, $\max .80 \mathrm{~km}$. wide) and lies along east-west direction. It has broad shelf in the south (38\% proportion to total Sea of Marmara area and $69 \%$ proportion to shelves) and narrower shelf in the north area (17\% proportion to total Sea of Marmara area and $31 \%$ proportion to shelves). Shelf area has a largest proportion among the other morphologic units in the Sea of Marmara (Gazioğlu, et al., 2002; 2017). The E-Woriented basin chain between the Gulf of İzmit and the Ganos Mountain System is called here the "Marmara Trough". The four basins are separated by ridges constituted in the E-W direction of Marmara Trough which coincides with the northern branch of the North Anatolian Fault Zone (NAFZ) (Gazioğlu, et al., 2005; 2014; 2016).

In the Sea of Marmara, the oldest sediments were deposited as a result of the transformation of the Sea of Marmara from a lacustrine environment to a marine environment with the Mediterranean Tyrenian transgression at the end of Middle Pleistocene. When the sea level in the Sea of Marmara is at the same or higher than the present day, water passage from the Black Sea has occurred. At the beginning of Late Pleistocene, as a result of a sudden drop in world sea level, the water passage from the Sea of Marmara to the Mediterranean was cut and the marine sedimentation environment was replaced by lacustrine sedimentation. At the beginning of Late Pleistocene (between 64.000-59.000 BC),
Mediterranean waters entered the Sea of Marmara and the Black Sea with the sudden rise of sea level (Algan et al., 2011; Gazioğlu et al., 2010). After the transgression, the gulfs and islands in the Sea of Marmara were formed.

The Sea of Marmara can be considered in two groups regarding its islands. Northern Marmara and South Marmara islands. South Marmara islands are; Marmara Island (117.2 km2), Paşalimanı Island (21.4 km2), Avşa Island (20.6 km2), Koyun, Ekinlik, Yer, Mamal1, Tavşan, Fener, (Asmalı), Hayırsız, Haliada, Eşek Islands of Balıkesir Province, and Imralı Island $(9.98 \mathrm{~km} 2)$ of Bursa. North Marmara Islands are Büyükada $(5.4 \mathrm{~km} 2)$, Heybeliada (2.5 km2), Burgaz (1.5 km2), Eşek, Sedef, Pide (Kaşık), Kınalıada, Sivriada, and Yassıada (Doğanay, 1997). In this study, physical geography features of these islands were analysed.

\section{Geological Evolution}

The Sea of Marmara is located in a geologically complex area. The formation of the Sea of Marmara, which is much younger than the Black Sea and the Mediterranean Sea, began with the arrival of the North Anatolian Fault in the Miocene - Pliocene. The Sea of Marmara consists of three pits with a depth exceeding one thousand meters and shelves surrounding these pits. These deep pits are also basins with Plio-Quaternary sedimentations with a thickness of several kilometers. The pits of the Sea of Marmara are deepening and filling grabens due to the movement of the North Anatolian Fault which cuts across the Sea of Marmara (Doğanay, 1997; Kaya \& Gazioğlu, 2015). The very narrow northern shelf of the 
Sea of Marmara is rising due to the movements of the North Anatolian Fault. The much larger southern shelf is shaped by normal faults. Elevations such as Marmara Island and Kapıdag form the base blocks of active normal faults. The Sea of Marmara is a very young geological area that is formed by the effect of the North Anatolian Fault. Although the formation of the Black Sea and the Eastern Mediterranean reaches 80 million years ago, Sea of Marmara is not present 10 million years ago (Görür et al., 1997; Sakınç et al., 1999; Kaya et al., 2008; Burak et al., 2009). The Sea of Marmara had been a terrestrial area covered with lakes and rivers. Following the arrival of the North Anatolian Fault in the region, the basins were formed as a result of the vertical movements along the fault, and the Sea of Marmara (Okay, 2007; Gökaşan eta 1., 2001; İsmail \& Gazioğlu, 2019) was formed as a result of the invasion of those basins by the sea.

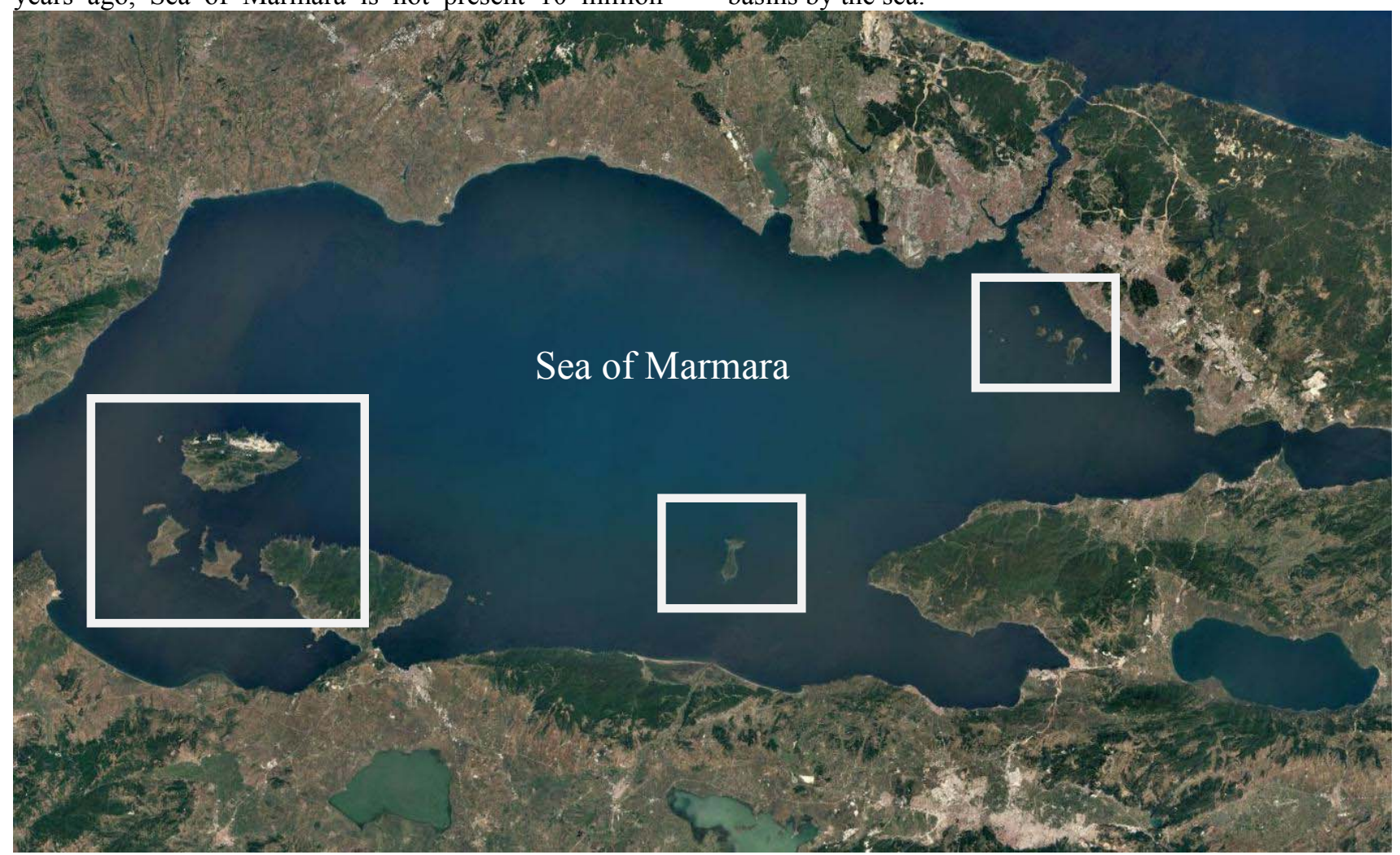

Figure 1. Study Areas.

\section{Geological Features}

Northern Marmara Islands that have been formed in a large time interval from the early Paleozoic to the present, covers a large number of rock-stratigraphy units (İ.B.B, 2009). However, Büyükada is very diverse in geologically.

The most common observed formation in the islands is Kinaliada Formation. This formation consists of sandstone - milestone with feldspar. The whole of Kinaliada and Burgazada and the major part of Heybeliada and the northern half of the Büyükada is composed of this formation. The Aydos Formation, which is composed of quartzites, has been distributed in the high sections in the southern part of Büyükada. Pelitli Formation which is composed of limestone and occasional clay interlayers is distributed in the whole of
Sedef Island and in the Northeast of Büyükada. In the south of the Büyükada, there is the Kartal member of the Pendik formation, which consists of limestones with limestone inter-bedded with mica scaly, clay-mile and thin clastic rocks. Another formation observed at the southwest of Büyükada is the Denizli Village Formation. This formation consists of limestone, clayey limestone, nodular limestone, and lidites. In some places, there is inter-bedded thin shale. Slope debris is frequently encountered on the slopes of the high sections of the northern Marmara islands. Especially east and northfacing slopes of Kinaliada there is debris fan that has been developed starting from the sea coast, reaching up to $40-50 \mathrm{~m}$ altitudes, becoming steeper as ascending down, and reaching the thickness of 20-30 m (Özgül, 2011; I.BB, 2009). In the coastal areas of the islands, a thin strip of sand dunes and alluvium deposits in the area have also been spread. 


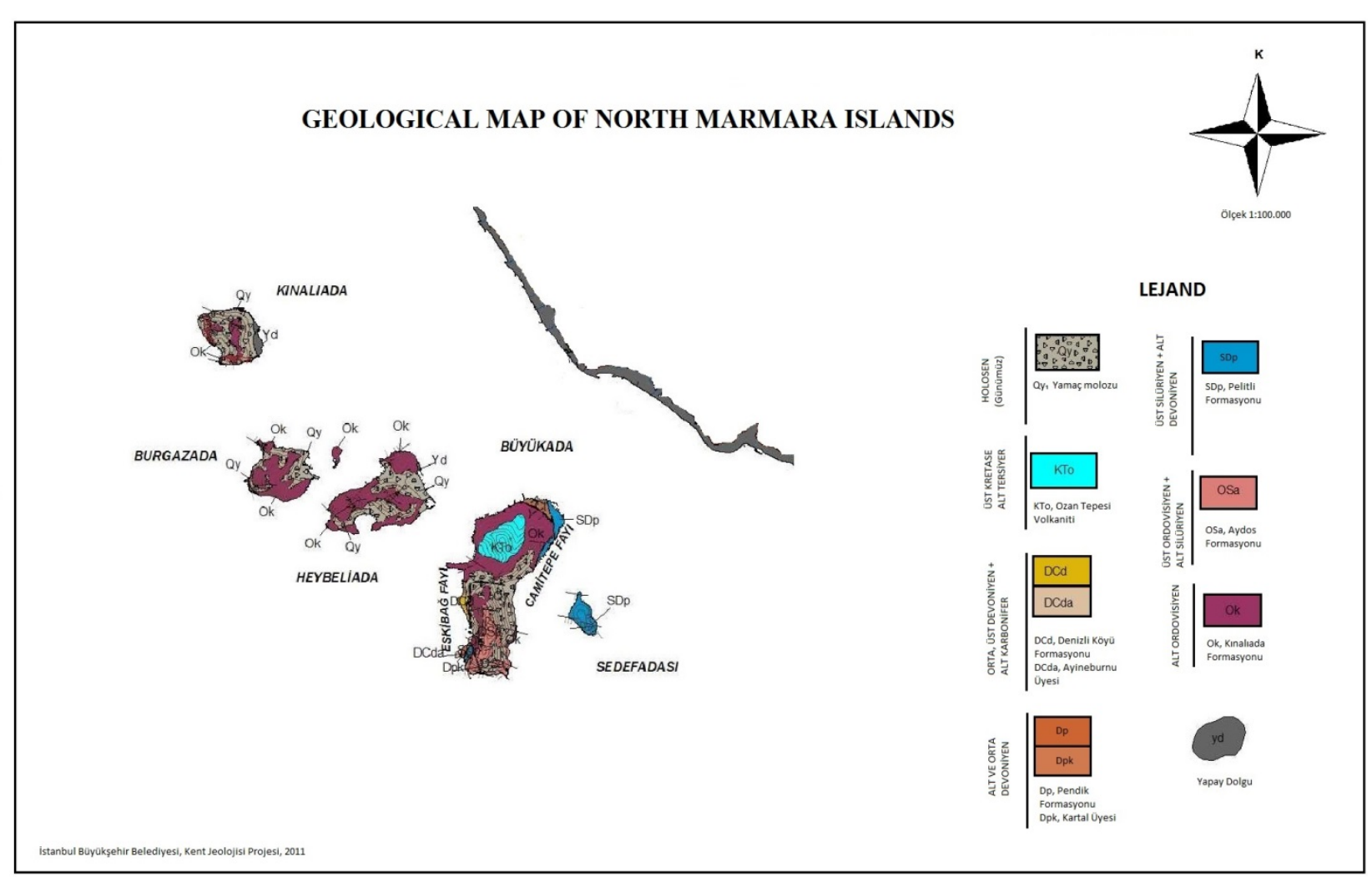

Figure 1. Geologicel Map of the North Sea of Marmara Islands.

When we examine Marmara, Paşalimanı, Avşa and Ekinlik islands of the South Marmara Islands from a geological point of view; the Marmara island is different in terms of geological units compared to others. The igneous rocks (metagranitoids, granitoids), metamorphic rocks and the "Q" quaternary period beaches, sand dunes and alluviums are dominant geological elements of these islands (M.T.A, 2016).

Geological units on the Marmara island generally extend in the west-east direction. As we move from the south to the north, we are moving to more juvenile units. Given the extension of the units and the slope of the beds, the island can be said to have a monoclinic appearance. The base of the island is composed of metamorphic schist series. These metamorphic schists remained in the form of enclaves between granite and granodiorites. Quartzites are also found in schist series. The metamorphic schists are made of marble and dolomitic marble. In some sections, the marble zone and the granodoritic intrusive series are next to each other. This marble belt covers almost the northern part of the island. In addition, alluvial deposits are also found in the creek mouths and coasts. The gneiss and granodiorites are dominant in Ekinlik and Avşa Islands, which are separated by a shallow threshold. In Paşalimanı, metamorphic schists are observed (Tunçdilek, 1987).

When we look at the geological structure of İmralı Island, it is possible to divide the island into two parts geologically. The rocks that formed the old core of the island and the quaternary strata of the island. The rocks forming the old niche form the hillsides to the north of the island. The area, which extends from the wide olive groves on the skirts of Çakmak Hill to the nose of the mill, consists of quartzite or arkose type hard sandstone. A series of schists and pink colored massive limestones can be seen. Since the sandstones are superficially covered with debris and altered, the contact of the schistlimestone series is not well visible (Pamir, 1941). Quaternary alluvial deposits on the shores of the valleys are also common. 


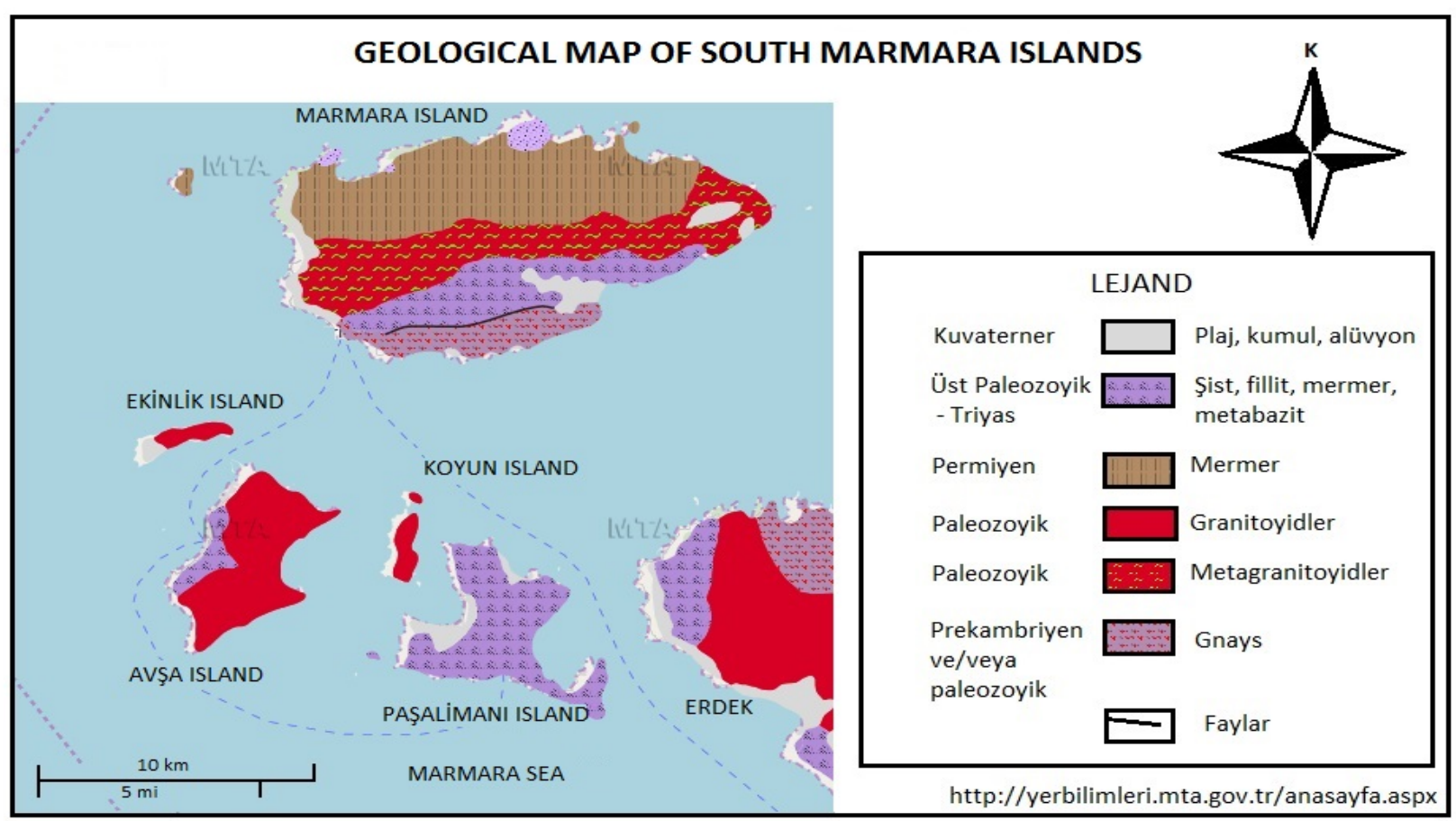

Figure 2. Geologicel Map of the Sea of Marmara south islands (Developed Ertek et al., 2015)

\section{Geomorphological Features}

Although the formation of the Sea of Marmara is out of the 4th Time, it is in the 4th Time that it reaches its final form (Ardel and İnandik, 1957). The formation and current development of the Sea of Marmara has developed under the control of the North Anatolian Fault. However, transgression and regression, which occurred as a result of climate changes between glacial cycles and interglacial cycles, were effective in the formation of the Sea of Marmara.

The Sea of Marmara can be divided into East-West direction morphologically. These are the deep part where the pits at depths up to $1335 \mathrm{~m}$ in the northern half and the shallow part limited to $100 \mathrm{~m}$ contour in the southern half. Particularly, the material brought by the rivers along the South Marmara coast is considered to have a partial role in the shallow and wide southern shelf. These two parts are separated from each other along the line of Armutlu Peninsula and Marmara Island (Barka et al., 1999; Smith et al., 1995).

Northwest of Turkey, within the province of Balikesir Southern Marmara (Team) Islands, occurred from dozens of rocky islands and islets with 24 . These islands, which have a total area of $165 \mathrm{~km}^{2}$, appear as a continuation of the Kapıdağ Peninsula in terms of structure and landforms, and were separated from the mainland as a result of the rise of the sea level at the end of the Fourth Time and gained their morphological characteristics (Van Andel, 1990; Lambeck, 1996; Lambeck et al., 2004; Vouvalidis et al., 2005; McHugh et al., 2008; Algan et al., 2011; Poulos et al., 2009; Scicchitanoa et al., 2011; Mourtzas, 2012).
The Marmara, Avşa, Paşalimanı and Ekinlik Islands, which we can consider as the South Marmara Islands, are structurally similar to the Kapıdag peninsula. This shows that all these islands could be a land that is integrated with Kapıdağ Peninsula. Although this island group in the South does not have very different features in terms of structural characteristics, it is slightly different in Marmara Island, which is the largest island of Sea of Marmara in terms of the diversity of the geological units and the tectonic activity.

The southern Marmara islands are in conformity with lithological and tectonic features. While the Marmara Island forms a mountain form, the islands of Ekinlik, Avsa, and Pasalimani consists of more low areas and hills. Marmara Island is very diverse in terms of topography and geomorphology compared to other islands. However, the Marmara Island represents all the units that make up the geological mass of the KapıdağGüney Marmara Islands and has been subjected to very severe tectonism (Tunçdilek, 1987). Marmara Island is morphologically higher and rugged; The islands of Paşalimanı, Avşa and Ekinlik have a more simple relevance. 1 / 500,000 scale Geological Map of Turkey in Istanbul Dies at judges geological units as specified on the islands of granite, marble and is composed of metamorphic series (MTA, 1964). Marble, crystallized limestone and dolomite dominate the northern part of the Marmara Island, the largest of the islands. In the southern part, the metamorphic schist, gneiss and granognays series are widespread. In the central part of the relatively large formations in the north and south of the Marmara Island, the series where the granite, granodiorite and quartz diorite develop are all of the same. The metamorphic series on Paşalimanı Island and on the Avşa and Ekinlik Islands granite are the dominant geological units. The variability in the lithological 
structure led to differentiation in the inclination values as well as the morphology in the islands and the peninsula.

As stated, the northern part of the Marmara Island has a lithological character where marble, crystallized limestone and dolomite are commonly found. As these formations are cracked and permeable, the groundwater level is low. This feature affects the general landscape and negatively affects the agricultural life in this region due to the lack of water. The marbles forming the bedrock are composed of dolomitic structure and consisting of monoclinal ridges and hills in the northern part of Marmara Island. Located in the northeastern part of the island, Badalan Bay is one of the most important agricultural areas developing parallel to the existing fracture lines and sheet directions.

The valleys divided by various small streams, and basins formed by the creeks, which are poured into the northern and southern shores of the island, are the first striking geomorphological units. There are steep cliffs in the northern part of Çınarlı Neighbourhood, to the west of the Saraylar and to the east of the Asmalı Village. Apart from this, sandy, gravelly and relatively shallow beach areas are also widely seen. On the island, there are also secondary fault lines that cut the east-west direction fault lines, in the north-south direction. This has resulted in the formation of some bays in the grabens that formed between the tectonic lines. Coasts are not overly protruding. Alluvial accumulation is not much in the littoral areas observed on the coasts (Doğan, 2009).

The other islands in the south have a plain appearance which is not geomorphological diverse due to excessive wear (Tunçdilek, 1987). Paşalimanı Island is formed by hills in a drainage basin west of it and a tombolo connected to it from the southwest. There is a lagoon in the area where Tombolo is connected with the island, and the village of Tuzla is located on the tombolo. Although relatively high coastal type is observed, the beaches around Paşalimanı and Harmanlı villages take a large place. In the Avşa Island, there are alluvial deposits formed by the transient streams in the west and east, while the central and northeaster parts of the southwestern coasts are relatively uneven. There are many big and small beaches on the coasts (Doğan, 2009).

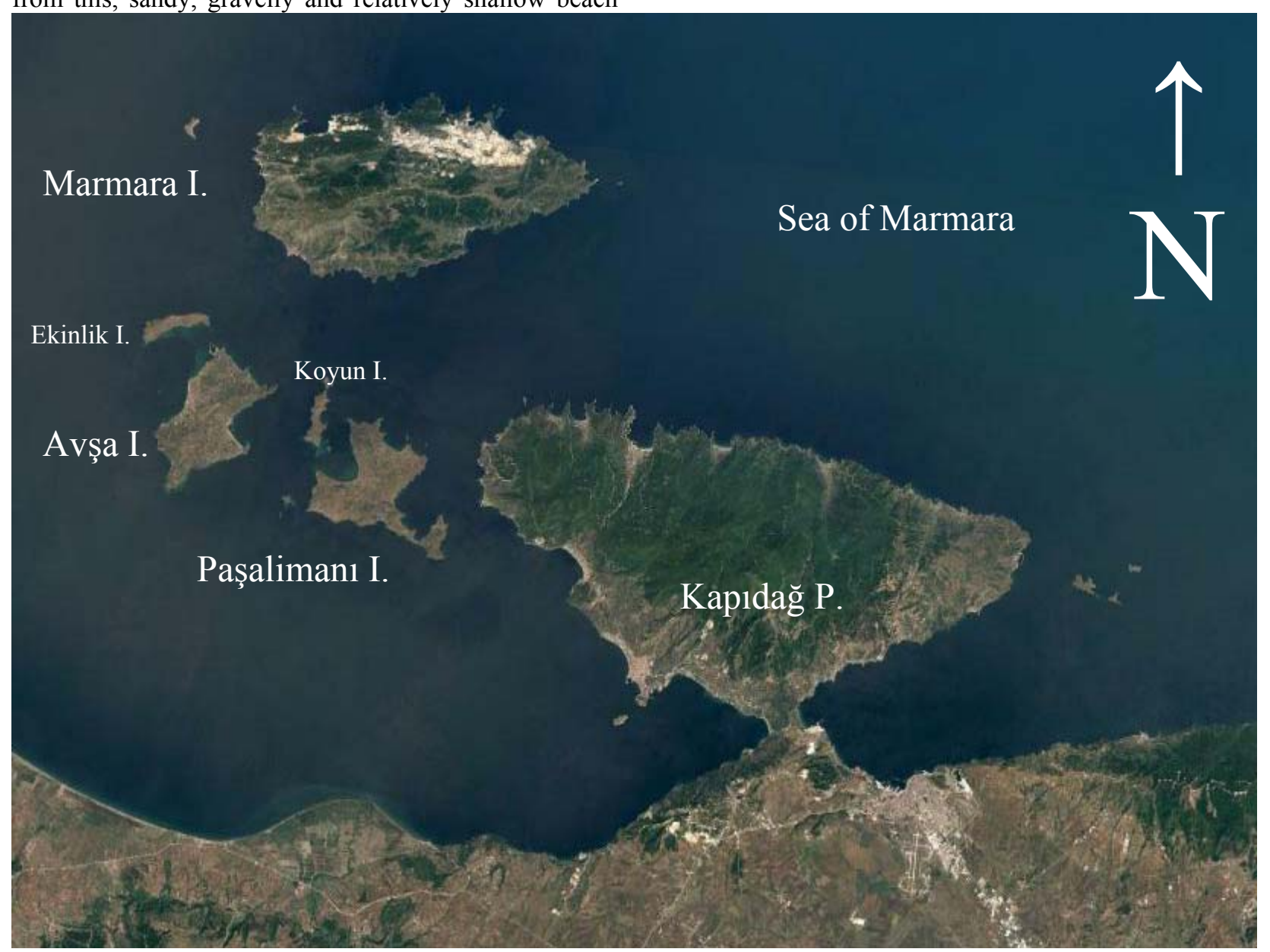

Figure 3. View from the west to the South Marmara Islands (Google Earth, 20.03.2019)

Another important island to be mentioned in South Marmara is İmralı Island of Bursa Province. The surface area is $9.98 \mathrm{~km} 2$ and the length of its coast is $19.4 \mathrm{~km}$. The distance between the North and the South most distant points is $6.8 \mathrm{~km}$ and the width of the East and the
West most distant points is $3.20 \mathrm{~km}$. The central part of the island is narrow, north and south parts are wide.

The highest point of the island is the Ataturk Hill, $217 \mathrm{~m}$ high. In addition, Kartaltepe, 113 m, Cakmaktepe, 190 
$\mathrm{m}$, Inonu Hill, $160 \mathrm{~m}$ are remarkable elevations on the island. Slightly sloping hills extending in steep cliffs towards the sea is the dominant view. In the central part of the island, there are few low heights towards the south from Inönü Hill. There is no permanent river on the island. However, many small valleys and flood beds indicate the presence of temporary streams (Pamir, 1941). The nine islands that are referred as North Marmara Islands in this study, which are 13-22 km away from Istanbul and 3-14 $\mathrm{km}$ away from the Anatolian coast of İstanbul and lying in the northwest-southeast direction, are called as İstanbul Islands (İ.B.B. 2010).

The northern Marmara Islands, on the other hand, are considered to be land fragments separated from the Kocaeli peninsula at the beginning of the 4th Time in terms of geological and topographical structure. It is also thought that Northern Marmara Islands are the fragments of the Thrace/Kocaeli peneplain remained over the water surface, as a result of the elevation and settling of this peneplain during the formation of our world, especially when the Straits were formed and the southern part of the peneplain was flooded by the sea waters. In the west of the islands, there are traces of a gulley, which is supposed to be the continuation of the Bosphorus channel, while there has been submerged valleys formed by streams were identified between islands (Öztürk, 2017). The whole of the northern Marmara Islands has a surface area of $16 \mathrm{~km} 2$. This island group has a plain topographical appearance. The coasts are generally in the form of curves with no nooks and crannies (Istanbul Provincial Directorate of Culture and Tourism, 2018).

From the geomorphological point of view, these islands are shaped by orogenic, epigenetic and eustatic movements, and have taken the morphological appearance of the present day by the influence of external forces. The existence of tectonic elevations and depressions due to the epirogenic movements is in the form of monadnoc islands with the effect of the eustatic movements in the Pleistocene (Telli \& Ekinci, 2012: $145)$. The layers forming the islands extend in the northsouth direction.

Northern Marmara islands are composed of dome structures consisting of durable rocks, and flats at the lower parts, consisting of schists, limestones, and sandstones with less durable rocks. These plains have been exposed to the erosion of the sea on both the islands and the peninsula. The islands are located on a platform rising towards the land, with an increasing elevation towards the southeast, and a slope of $7 / 1000$, with a mean depth of 50 meters. On this platform, there are hilly areas, erosion surfaces, old river valleys, neck, ridge, marine terraces, and coastal morphology units. Given all these geomorphological features, it is highly probable that the platform is a surface formed on land (Ardel, A. 1957).

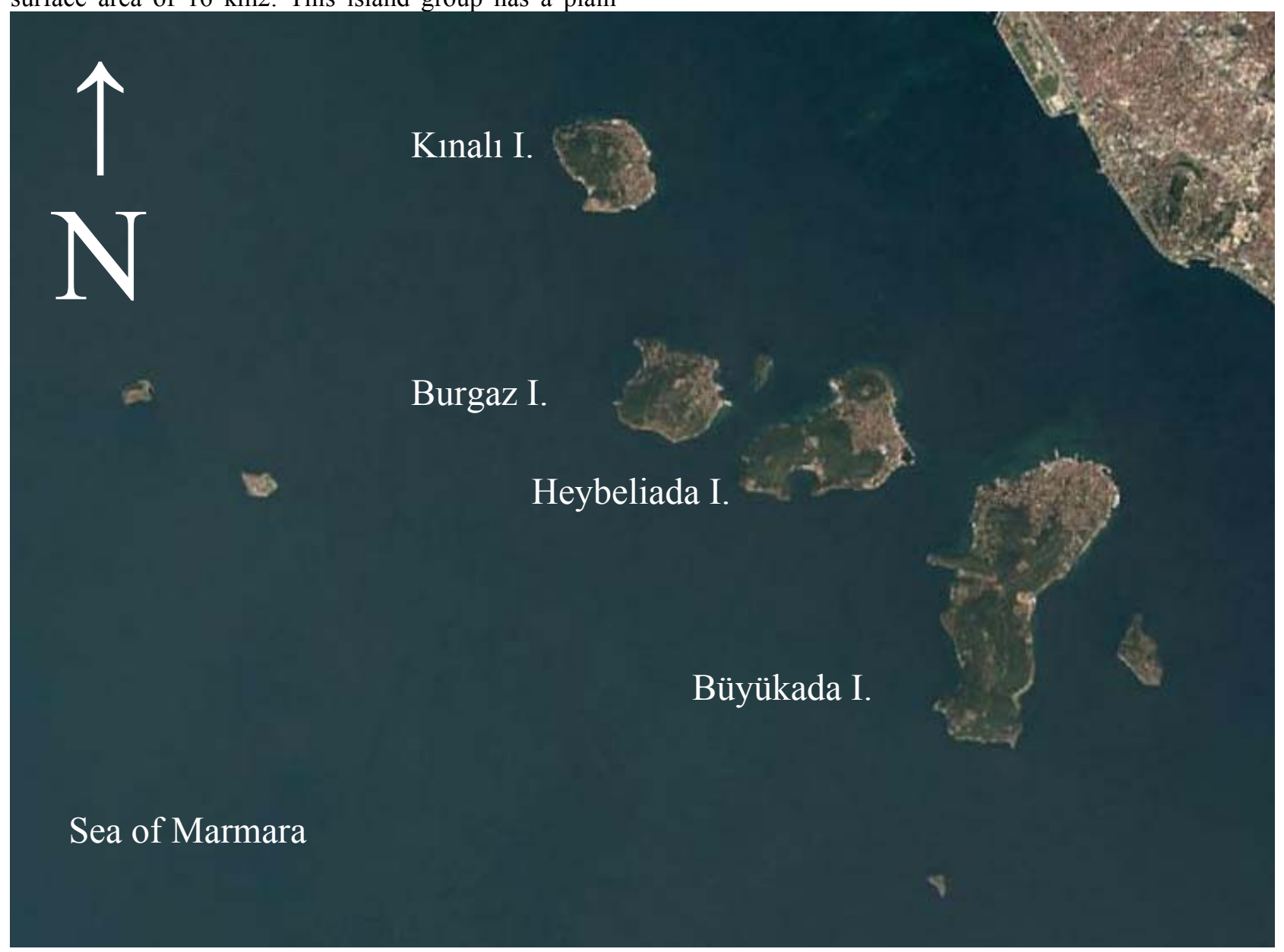

Figure 4. A view of the North Marmara Islands from the northwest (Google Earth, 23.01.2019). 
The marine terraces seen at many points on the shores of the Sea of Marmara are also observed on the islands. The terraces observed at the level of $12-18 \mathrm{~m}$ due to the influence of Flanders transgression have been damaged due to erosional effects and current deposits. The coastal morphology units are observed on the islands due to the wave, the impact of sea currents and the $44 \mathrm{~km}$ long coastal length of the islands. These units consist of cliffs, sandy and pebbly beach areas, abrasion platforms and remains of rock erosion. The cliffs are seen on the southern shores of the islands, while the beach areas are observed on the northern shores. In this case, the direction of sea currents was effective. This element of the morphological structure, especially in the residential area, has affected the distribution of many types of space utilization (Garipağaoğlu \& Ozcan, 2016). As the islands are exposed to too much wear, they do not have a very hilly appearance, which is quite plain and without much elevation. Yüce (Aya Yorgi 203 m), İsa (Hristos 163 m), Tepeköy (Nevruz $150 \mathrm{~m})$, Avc1 (145 m) hills on Büyükada; Mill (136 m), Köy (128 m), Makarios (98 m), Umit $(85 \mathrm{~m}$ ) hills on Heybeliada; Bayrak (Hristos 170 $\mathrm{m})$ on Burgazada; Çınar (115 m), Tesvikiye (115 m), Manastır $(93 \mathrm{~m})$ on Kinaliada can be counted among the most important of these hills. Many of these peak areas specified also form the abrasion surfaces. Neck, ridge and dried river valleys between hilly areas form geomorphological connections (Garipağaoğlu \& Özcan, 2016, ; Kaya et al., 2008).

\section{İmralı Island}

It is approximately 10.8 nautical miles $(20 \mathrm{~km})$ from Bozburun at the western end of the Armutlu Peninsula and 6.5 nautical miles $(12 \mathrm{~km})$ from the mouth of the Susurluk Creek on the Black Sea coast of Bursa. Bursa remains within the boundaries of the province, nowadays there is no settlement. Marmara is the fourth largest island in Sea of Marmara after Paşalimanı and Avşa. Its surface area is $19.4 \mathrm{~km}$ with $9,99 \mathrm{~km} 2$ coast. The middle of the island is a mile in width. In this way the middle part is very narrow up and down in a wide regular form. It has a roughly hourglass or 8-digit format. The main axis following the north-south direction reaches $6.5 \mathrm{~km}$. Its width up to $3 \mathrm{~km}$ in the north narrows down to $620 \mathrm{~m}$ in the middle; it expands to the south. The higher northern section reaches $217 \mathrm{~m}$ in Bahritepe. The southern section is lowered and ends in Siğburun.

At the $113 \mathrm{~m}$ altitude towards Kartarepe at an altitude of $190 \mathrm{~m}$, Çakmak Tepe closed at the altitude of $210 \mathrm{~m}$ at Atatürk altitude and at $115 \mathrm{~m}$ altitude at the altitude of $115 \mathrm{~m}$. From the level of the mill that is the center of this day, from the level of the mill in the song, from a line leading to the most bitterly cliff of the island, the land of the island slowly descends towards the cenuba and garba with its wide ridges. In the central part of the island there are $160 \mathrm{~m}$ high İnönü Hill and more low hills with no names. In this way, the surface of the island is responsible for the cenuba and garba.

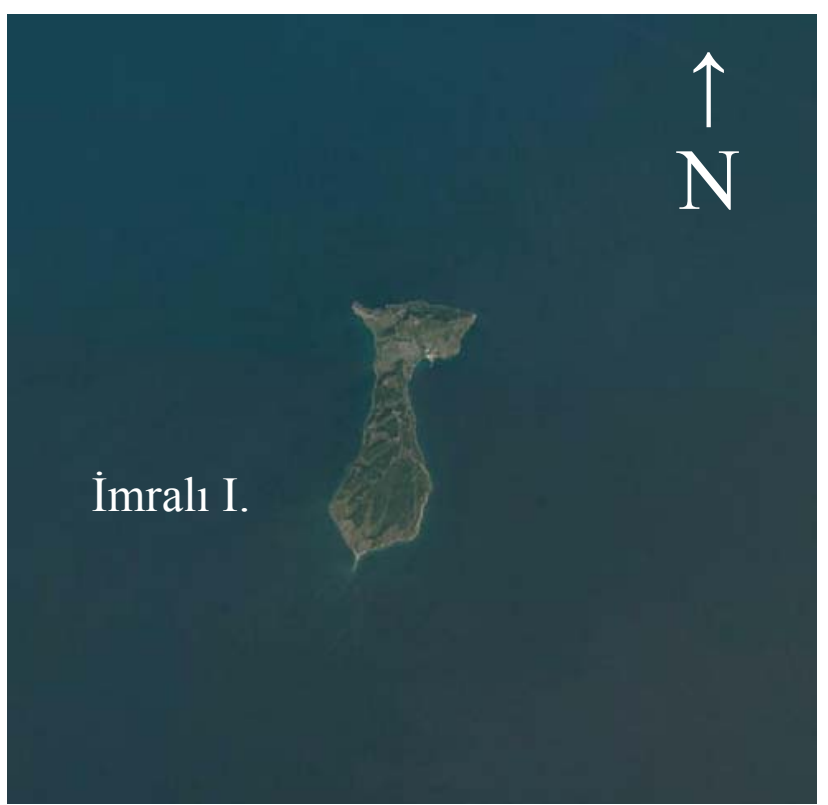

Figure 5. A view of the North Marmara Islands from the northwest (Google Earth, 23.01.2019).

There is no permanent water flowing on the island. However, many small valleys and flood beds indicate the presence of temporary flows. The most important of these is the dry river bed which is located on the side of the island and has a wide valley floor in the direction of Şimal-Cenen. This river has a feeding basin of approximately $2 \mathrm{~km} 2$. Another one is the creek bed which comes from the foothills of İnönü Hill and from here to the garba. This has a very large basin. The geology of the island. It is possible to separate Imralı Island into two parts in geology care.

- $\quad$ The old cores of the island,

- Quaternary layers which have given the island its present shape.

\section{Hydrologic and Hydro-geological Characteristics}

In the northern Marmara Islands, the groundwater level in alluvial, landfill and beach sedimentations varies between 1 to 10 meters. The groundwater level on the slopes is over 5 meters (Yertek Mühendislik, 2001). Springs, ponds and stream types in the North Marmara Islands are almost nonexistent. For this reason, water is supplied from the mainland of Istanbul to the islands which are not self-sufficient in terms of drinking water.

South Marmara Islands are quite poor in terms of groundwaters. In winter, while the people of the island benefit from this groundwater, this underground water is not enough due to the increasing population in the summer. Therefore, desalinized and refined sea water is utilized in those islands.

\section{Soil properties}

In the areas of the North Marmara Islands, where there is no vegetation on the mainland, the decomposition starting on the bedrock continues with algae, lichens, and seaweed; in areas with vegetation, decomposition continues with microflora, macroflora, and mesofauna. 
Although the climatic and vegetation characteristics of the islands are suitable for soil formation, which are located in a climate zone close to the Mediterranean climate, most of them lack a horizonated ground cover. The fact that the topography is very inclined almost everywhere causes the material to be displaced and swept. For this reason, the present red colored soil layer has become very thin and the bedrock has been exposed. Where the plant population is relatively bushy, the red soil is covered with a very thin debris that consists very little humus, and made of decayed and crumbled leaves. The colour of the soil becomes darker, only in that area. The soil is red in places where organic debris is not formed or swept.

Relatively thicker slope debris mixed with red soil is located at alluvial fields. On top of these, there is a thin covering layer containing rotten organic debris and a small amount of raw humus. Therefore, the colour of the soil has a darker appearance. The red colored soils, which are mentioned above and which is the origin of the name of the Red Islands given to the Istanbul Islands, consist of iron oxide and aluminum oxide. Gives a Clayey and granular appearance.

The lateritic red soils of the islands belong to Podzols, possibly matured in a humid term. Therefore, the Islands have recently shown that the climate has shown a warm and humid feature for a long time.

Finally, we can say that the thickness of the soil and humus in the Islands are low and that the richness of the rock in terms of silicium constitutes the basis for limiting the development activities of the plants. Besides, the fact that the main rock is killed with diaclases increases the water loss of the soil (M.S.Ü. 1987;.B.B. 2010).

On the other hand, granodiorites form the basis of the ground in the South Marmara Islands. The sandy soil group emerged with the decomposition of the granodiorite rock. The fact that sandy soil occupies the largest area in the field is related to the widespread appearance of granodiorite rock in this area. This soil group formed by the decomposition of granodiorite is poor both in texture and nutrients (Atalay, 2005., Ok, 2018). Apart from that, coastal dunes and alluviums are observed in the field.

\section{Climate Characteristics}

The climate of the North Marmara Islands is similar when compared to the meteorological stations in Istanbul and the islands. Just like in Istanbul, the Marmara climate, where the effects of the Mediterranean, the Black Sea, and continental climates are observed together, can be seen. However, the effects of the Mediterranean climate are felt more in this region, as it is located in the south, unlike Istanbul. For this reason, a few degrees of temperature differences with Istanbul are observed.

Dominant wind direction year around in the North Marmara Islands is west. Occasionally, Northern winds become more effective. In the transition of the seasons, the western winds in winter and the eastern wind in summer, increase their influence on the islands. In the winter, it is dominated by the cold and rainy weather coming from the north. It is hot and dry in summers. Lighter climatic conditions prevail compared to Istanbul with the influence of the Mediterranean climate.

When we look at the climate characteristics of the Marmara Team Islands in a general framework, it can be stated that they carry the main character of Mediterranean macroclimate type. However, it is seen that the summer is not as hot and dry as the Mediterranean type, the highest average temperature does not exceed $24.6^{\circ} \mathrm{C}$ and rainfall does not fall below $14.4 \mathrm{~mm}$ in the warmest month. Winters are cool according to the Mediterranean climate type, but not very cold. Even in January, the coldest month, the average temperature does not fall below $6^{\circ} \mathrm{C}$. The Marmara Islands remain under the influence of the general mass air masses in winter and receive abundant frontal rainfall. In the spring and summer periods when the efficiency of tropical air masses increased, precipitation is lower. Especially the summers are quite dry. Summer precipitation usually falls on the odd days and as a result of some convective events. The average annual precipitation of the Marmara Islands is 733.4 $\mathrm{mm}$. The evaporation values of the islands are high in the period between May and October. In a way that causes drought, especially in the winter rainy rainfall can significantly close this lack of evaporation. Snowy days and snowfall is not much on the islands is a little high cloudiness. However, the number of open days is also high. With the above mentioned climatic features, Marmara Islands has a slightly changed subtropical air conditioner. Turkey's climate throughout the bur "Marmara transition type" can be called.

\section{Fauna}

The islands of the Sea of Marmara vary greatly from a biological and ecological point of view. In particular, the Northern Marmara Islands have a wide variety of vegetation due to the fact that the Black Sea, the Mediterranean and the continental climate of which we call the Marmara climate, are seen together.

North Marmara Islands is home to 615 hectares of forest. Those forests are two types as coniferous and latifolious. Dominant forest structure is coniferous. The most frequent trees are pinus brutia, pinus pinea, and maritime pine. The mean elevation of those islands is $0-200 \mathrm{~m}$. The predominant vegetation in this elevation is also made up of trees, shrubs and herbaceous plants (I.BB, 2010). Other than that, there are also rich arrays of plants.

South Marmara Islands are located in Europe-Siberia realm (Atalay, 1994). The islands where shrubs and herbaceous plants dominate are quite poor in terms of trees. Among the plant species that dominate the islands are Garig species, Sarcopoterium spinosum, Cistus salviifolius, Cistus creticus, Lavandula stoechas, and 
Centaurea spinosa, which is closely related to edaphic conditions. Spartium junceum, one of the maquis formations, is another species observed in the area. In addition, Juncus maritimus, Equisetum sp. and Narcissus sp. are other species observed in the field, though rarely seen $(\mathrm{Ok}, 2018)$. Olive trees are prevalent. Occasionally swamps can be seen.

\section{Conclusion}

As it is understood from our study, the Sea of Marmara islands, which are geographically located very close to each other, show similar features in terms of physical geographic features. Geologically and geomorphological, the islands which do not have much diversity are very similar to each other in terms of climate characteristics, and have a weak ground cover and thus, weak vegetation. Due to the fact that the islands are on a strong bedrock and the slow activity of the internal and external forces, there is no rapid change in geological and geomorphological aspects.

As a result of this research, it has been seen that scientific researches on the islands, especially on the South Marmara islands, are insufficient. Unfortunately, similar studies have not reached the desired level due to both the financial difficulties and the lack of interest of the local administrations and other institutions and organizations on the islands, related to these issues. For this reason, more financial and educational support should be provided to geographical researches on the South Marmara Islands.

Although it is a neighbour to one of the biggest metropolis (Istanbul) in the Marmara region, it is not possible to say that the Sea of Marmara southern islands are sufficiently studied. One of the most important results of this study is the fact that more in-depth researches on the investigation of the endemic species from the region in general. Although the Sea of Marmara southern islands host the settlement throughout almost all human history, they have unique characteristics that make island biodiversity so special also leave it particularly fragile and vulnerable. Despite the high levels of biodiversity and the prevalence of endemism, island species are contemporary in relatively small numbers, making them identical vulnerable to disappearance.

Through the identification of all the morphological and human characteristics of the islands of the Marmara Region, especially within the framework of integrated coastal zone management, these areas can be transformed into a laboratory. However, the ongoing mining activities on the islands and the local tourism practices increase the pressure on the islands in the south of the Sea of Marmara. For the islands that are located in the north and whose use is shaped by the intense pressure of Istanbul, it is useful to re-examine an integrated coastal zone management model that includes urban demands within the framework of local governance and local interest.

\section{References}

Algan, O., Yalçın, M., Özdoğan, M., Yılmaz, Y., Sarı, E., Kırcı-Elmas, E., Yılmaz, İ., Bulkan, Ö., Ongan, D., Gazioğlu, C., Nazik, A., Polat, MA. \& Meriç, E. (2011). Holocene coastal change in the ancient harbor of Yenikap1-İstanbul and its impact on cultural history. Quaternary Research, 76(1), 30-45. doi:10.1016/j.yqres.2011.04.002.

Ardel, A. \& İnandık, H. (1957). Marmara Denizi'nin Teşekkülü ve Tekamülü,TCK, Vol17, 1-19.

Ardel, A. (1957). Marmara Denizalt1 Reliefi, Istanbul Üniversitesi, Coğrafya Enstitüsü Dergisi, 108.

Atalay, İ. (1994). Türkiye Vejetasyon Cografyası. İzmir: Ege Üniversitesi Yayınları.

Atalay, İ. (2005). Kuvaterner'deki İklim değişimlerinin Türkiye Doğal Ortamı Üzerindeki Etkileri, Türkiye Kuvaterner Sempozyumu.121-128

Barka, A., Sakınç, M. \& Yaltırak, C. (1999). Türkiye Denizleri'nin ve Çevre Alanlarının Jeolojisi. Ulusal Deniz Jeolojisi ve Jeofiziği Programı, Tübitak Üniversite-MTA.

Burak, S., Ünlü, S. \& Gazioğlu, C. (2009). Environmental stress created by chemical pollution in the Sea of Marmara (Turkey). Asian Journal of Chemistry, Vol. 21(4). 3166-3174

Büyüksalih, İ. \& Gazioğlu, C. (2019). New Approach in Integrated Basin Modelling: Melen Airborne LIDAR, International Journal of Environment and Geoinformatics (IJEGEO), 6(1): 22-32. doi: 10.30897/ijegeo.530272.

Doğan, S.Ö. (2009). Beşeri Coğrafya Açısından Marmara Takım Adaları, Çantay Kitapevi, İstanbul.

Ertek, TA., Kılıç, E., Erginal, AE., Ekinci, YL. Demirci, A. (2015). Preliminary Assessment of Submerged Beachrock and Tsunamigenic Deposit, Hasir Island, Marmara Archipelago, Journal of Coastal Research, Vol. 31(2): 428-433.

Garipağaoğlu, N \& Özcan, S. (2016). İstanbul Adaları'nın Mekân - Kıyı Yönetimi ve Sürdürülebilirlik Kapsamında Planlanması. Marmara Cogrrafya Dergisi, Sayı: 33, İstanbul

Gazioglu C, Gokasan E, Algan O, Yucel ZY, Tok B, \& Dogan E (2002) Morphologic features of the Sea of Marmara from multibeam data. Marine Geology, 190:397-420.

Gazioğlu C, Yucel ZY. \& Dogan E (2005) Morphological features of major submarine landslides of Sea of Marmara using multibeam data. J Coastal Research, Vo. 21:664-673.

Gazioğlu C., Burak,S., Alpar, B., Türker, A. \& Barut, IF. (2010) Foreseeable impacts of sea level rise on the southern coast of the Sea of Marmara (Turkey), Water Policy, Vol 12(6), 932-943.

Gazioğlu, C (2017). Assessment of Tsunamirelated Geohazard Assessment for Hersek Peninsula and Gulf of İzmit Coasts. International Journal of Environment and Geoinformatics (IJEGEO), 4 (2), 63-78. doi: 10.30897/ijegeo.312554.

Gazioğlu, C., Akkaya, M.A., Baltaoğlu, S. \& Burak, S.Z. (2016). ICZM and the Sea of Marmara: The İstanbul Case. The Sea of Marmara: Marine Biodivesity, Fisheries, Conservations and Governanace (Editors: 
Özsoy, E., Çağatay, M.N., Balkıs, N., Balkıs Çağlar, N., Öztürk, B.), 935-957.

Gazioğlu, C., Alpar, B., Yücel, ZY., Müftüoğlu, AE., Güneysu, C. \& Ertek, TA. (2014). Morphologic Features of Kapıdağ Peninsula and its Coasts (NWTurkey) using by Remote Sensing and DTM. International Journal of Environment and Geoinformatics (IJEGEO), 1(1), 48-63. doi: 10.30897/ijegeo.300739.

Gökaşan, E.; Alpar, B.; Gazioğlu, C.; Yücel Z.Y.; Tok, B.; Doğan, E. \& Güneysu, C. (2001). Active tectonics of the İzmit Gulf (NE Sea of Marmara): from high resolution seismic and multi-beam bathymetry data. Marine Geology, 175/1-4, 271294.

Görür, N., Çağatay, M.N., Sakjnç, M., Sümengen, M., Şentürk,K., Yaltırak, C. \& Tchapalyga, A. (1997). "Origin of the Sea of Marmara as deduced from Neogene to Quaternary paleobiogeographic evolution of its frarne. International Geology Review, 39.

İ.B.B. (2009). İstanbul Mikrobölgeleme Projesi Anadolu Yakası Ístanbul Büyükşehir Belediyesi Deprem Risk Yönetimi ve Kentsel Iyileştirme Daire Başkanlı̆̆l Deprem ve Zemin Inceleme Müdürlüğü, Cilt 1.

İ.B.B. (2010). 1/50000 Ölçekli Adalar Koruma Amaçlı Nazım İmar Planı Raporu. İstanbul Büyükşehir Belediyesi Imar ve Şehircilik Daire Başkanliğı Şehir Planlama Müdürlüğü, cilt I-II, İstanbul.

İstanbul İl Kültür ve Turizm Müdürlüğü. (2018). Istanbul (Adalar)

Kaya, H. \& Gazioğlu, C. (2015). Real Estate Development at Landslides. International Journal of Environment and Geoinformatics (IJEGEO), Vol. 2(1), 62-71. doi: 10.30897/ijegeo.302433.

Kaya, H., Yücel, Z.Y. \& Gazioğlu, C. (2008). Marmara Denizi Adalarına Coğrafi bir Bakış, Ulusal Jeomorfoloji Sempozyumu, 185.

Kaya, H., Yücel, Z.Y., Doğan, E \& Gazioğlu, C. (2008). "İstanbul'un Marmara Denizi Kiyılarında Heyelan Riski” Türkiye’ nin Klyı ve Deniz Alanlarl VII. Ulusal konferansl, Türkiye Klyıları 08 Konferans Bildirileri Kitabı, 986,997, 27-30 May 2008, Ankara.

Lambeck, K. (1996). Sea-level changes and shoreline evolution in Aegean Greece since Upper Paleolithic time. Antiquity 70, 588-611.

Lambeck, K., Anzidei, M., Antonioli, F., Benini, A., and Esposito, A. (2004). Sea level in roman time in the Central Mediterranean and implications for recent change. Earth and Planetary Science Letters 224, $463-575$.

M.S.Ü. (1987). Marmara Takım Adaları Plan Araştırma Raporu, M.S. Ü. Döner Sermaye İşletmesi, 21s.

M.T. A. (2016). Maden Teknik ve Arama Genel Müdürlüğü, Yerbilimleri Harita Görüntüleyici ve Çizim Editörü, Version 2,9, Bilimsel Dokümantasyon ve Tanitma Dairesi, Ankara.

McHugh, C.M.G., Gurung, D., Giosan, L., Ryan, W.B.F., Mart, Y., Sancar, U., Burckle, L., \& Cagatay, M.N. 2008. "The last reconnection of the Sea of Marmara (Turkey) to the World Ocean: A paleoceanographic and paleoclimatic perspective". Marine Geology 255, 64-82.
Mourtzas, N.D. (2012). Fish tanks of eastern Crete (Greece) as indicators of the Roman sea level. Quaternary International 250, 3-18.

MTA. 1964. 1/500.000 Ölçekli Türkiye Jeoloji Haritası (İstanbul Paftas1).

Ok, D. (2018). Türkeli (Avşa, Marmara - Balıkesir) Adasının Kıyı Kullanımı ve Planlaması, Balıkesir Üniversitesi Sosyal Bilimler Enstitüsü, Yüksek Lisans Tezi (Basılmamış).

Okay, A.I., Mater, B., Artüz, O.B., Gürseler, G., Artüz, M.L. \& Okay, N. (2007). Bilimsel Açıdan Marmara Denizi, Türkiye Barolar Birliği ve Sevinç-Erdal İönü Vakf Yayını.

Özgül, N. (2011). İstanbul İl Alanının Jeolojisi” İstanbul Büyükşehir Belediyesi, Deprem Risk Yönetimi Ve Kentsel İyileştirme Daire Başkanlığı, Deprem ve Zemin İnceleme Müdürlüğü, İstanbul Kent Jeolojisi Projesi.

Pamir, H.N. (1941). İmarlı Adası'nın Jeolojik Etüdü, MTA Raporları, Jeoloji Etütleri Dairesi Başkanlı̆̆̆, Rapor No: 1276, Ankara.

Poulos, S. E., Ghionis, G., \& Maroukian, H. (2009). Sealevel rise trends in the Attico- Cycladic region (Aegean Sea) during the last 5000 years. Geomorphology 107, 10-17.

Sakınç, M., Yaltırak, C. \& Oktay, F.Y. (1999). Palaeogeographical evolution of the Thrace Neogene basIn and the Tethys-Paratehys relations at northwestern Turkey (Thrace). Palaeo. Palaeo, 153.

Scicchitanoa, G., Lo Presti, V., Spampinato, C. R., Gasparo Morticelli, M., Antonioli, F., Auriemma, R., Ferranti, L. \& Monaco, C. (2011). Millstones as indicators of relative sea-level changes in northern Sicily and southern Calabria coastlines, Italy. Quaternary International 232, 92-104.

Smith, H., Taymaz, T., Oktay, F., Yüce, H., Alpar, B., Başaran, H., Jackson, A.j., Kara, S. \& Şimşek,U. (1995). High resolution seismic profiling in the Sea of Marmara (NW Turkey: Late Quarenary sedimentation and Sea Level changes, GSA Bull. 107/8, 923-936.

Telli, S. \& Ekinci, D. (2012). İstanbul Adaları'nın Jeomorfolojisi, III. Ulusal Jeomorfoloji Sempozyumu Bildiriler Kitabı, Hatay.

Tunçdilek, N. (1987). Marmara Adaları, Istanbul Üniversitesi Deniz Bilimleri ve Coğrafya Enstitüsü Yayınlarl, No:7.

Van Andel, T.H. (1990). Addendum to 'late quaternary sea level changes and archaeology Antiquity 64, 151152.

Vouvalidis, K.G., Syrides, G.E. \& Albanakis, K.S. (2005). Holocene morphology of the Thessaloniki Bay: Impact of sea level rise. Zeitschrift für Geomorphologie N.F. Supplement 137, 147-158.

Yertek Mühendislik (2001). Adalar District Geologicalgeotechnical Research Report, 29. 